\title{
PENGARUH PELUMASAN TERHADAP KEAUSAN ALUMINIUM MENGGUNAKAN MESIN TWO DISK TRIBOMETER PADA 1000 RPM
}

\author{
Ahmad Rif'an \\ Fakultas Teknik, Program Studi Teknik Mesin \\ Universitas Muria Kudus \\ Email: ahmadrifan95@gmail.com \\ Taufiq Hidayat \\ Fakultas Teknik, Program Studi Teknik Mesin \\ Universitas Muria Kudus \\ Email: taufiq.hidayat@umk.ac.id \\ Rochmad Winarso \\ Fakultas Teknik, Program Studi Teknik Mesin \\ Universitas Muria Kudus \\ Email: rochmad.winarso@umk.ac.id
}

\begin{abstract}
ABSTRAK
Aluminium memiliki rasio kekuatan terhadap massa yang paling tinggi, sehingga banyak digunakan sebagai bahan komponen mesin, misalkan gesekan yang terjadi pada piston rem yang merupakan komponen penggerak dari sistem kerja rem hidrolis. Akibat dari kerja komponen tersebut maka akan timbul adanya pengikisan permukaan komponen.Tujuan penelitian ini adalah untuk mengetahui fenomena keausan alumunium 6020 alloy dengan menggunakan metode pengujian two disk tribometer, yang dilakukan dengan pelumasan dan tanpa pelumasan pada pembebanan $10 \mathrm{~kg}$ dengan kecepatan putaran $1000 \mathrm{rpm}$, dan waktu 60 menit, setiap 10 menit dilakukan pengukuran keausan pada spesimen.Hasil pengujian keausan pada spesimen yang terbuat dari material aluminium 6020 alloy dengan menggunakan pelumasan SAE 10W-30 dan tanpa pelumasan memperoleh kesimpulan bahwa setiap menit keausan pada disk meningkat, keausan dengan pelumasan mempengaruhi laju keausan pada spesimen uji dengan nilai rata-rata laju keausannya sebesar $0,000466 \mathrm{~mm}^{3} / \mathrm{N} . \mathrm{m}$, sedangkan rata-rata laju keausan pada tanpa pelumasan sebesar $0,000784 \mathrm{~mm}^{3} / \mathrm{N}$.m. Laju keausan tanpa pelumasan lebih besar dari laju keausan dengan menggunakan pelumasan
\end{abstract}

Kata kunci: keausan, alumunium, putaran, pelumasan, two disk tribometer.

\section{ABSTRACT}

Aluminium has the power to mass ratio is the highest, so widely used as engine components, eg the friction on the brake piston which is drive components of hydraulic brake systems work. As a result of these components working then there will be the erasur of the surface of the component. The purpose of this reasearch is to investigate the wear phenomenon of aluminum 6020 alloy using two disk Tribometer, performed with lubrication on loading $10 \mathrm{~kg}$ and varying the rotational speed of $1000 \mathrm{rpm}$ and 60 minutes, every 10 minutesmeasurement of wear on the specimen.The results of testing the wear of specimens made is material aluminum 6020 alloy by using lubrication SAE 10W-30 and without lubrication the conclusion that every minute of wear on the disk increases, wear by lubrication affect the wear rate on test specimens with the value of the average wear rateis $0,000466 \mathrm{~mm}^{3} / \mathrm{N} . \mathrm{m}$, while the average wear rate on without lubrication is $0,000784 \mathrm{~mm}^{3} / \mathrm{N} . \mathrm{m}$. Without lubrication wear rate greater than the wear rate by using lubrication

Keywords: wear, aluminium, rotation, lubrication, two disk tribometer.

\section{PENDAHULUAN}

Pada saat mesin beroperasi, komponen-komponen mesin akan saling bersinggungan dan mengalami sebuah kontak dan gesekan sesame komponennya, misalkan gesekan yang terjadi pada piston rem yang merupakan komponen penggerak dari sistem kerja rem hidrolis.Akibat dari kerja component tersebut maka akan timbul adanya pengikisan permukaan komponen atau sering disebut keausan (wear). 
Aluminium merupakan logam ringan yang mempunyai ketahanan korosi yang baik dan hantaran listrik yang baik dan sifat - sifat yang baik lainnya sebagai sifat logam. Sebagai tambahan terhadap, kekuatan mekaniknya yang sangat meningkat dengan penambahan $\mathrm{Cu}, \mathrm{Mg}, \mathrm{Si}, \mathrm{Mn}, \mathrm{Zn}, \mathrm{Ni}$, dsb. Secara satu persatu atau bersama-sama, memberikan juga sifat-sifat baik lainnya seperti ketahanan korosi, ketahanan aus, koefisien pemuaian rendah. Material ini dipergunakan di dalam bidang yang luas bukan saja untuk peralatan rumah tangga tapi juga dipakai untuk keperluan material pesawat terbang, mobil, kapal laut, konstruksi. [1]

Metoda pengolahan logam Aluminium adalah dengan cara mengelektrolisis Alumina yang terlarut dalam Cryolite. Metoda ini ditemukan oleh Hall di AS pada tahun 1886 dan pada saat yang bersamaan oleh Heroult di Perancis. Cryolite, bijih alami yang ditemukan di Greenland sekarang ini tidak lagi digunakan untuk memproduksi Aluminium secara komersil. Penggantinya adalah cairan buatan yang merupakan campuran Natrium, Aluminium dan Kalsium Fluorida. Aluminium murni, logam putih keperak-perakan memiliki karakteristik yang diinginkan pada logam. Unsur ini ringan, tidak magnetic dan tidak mudah terpercik, merupakan logam kedua termudah dalam soal pembentukan, dan keenam dalam soal ductility. Aluminium banyak digunakan sebagai peralatan dapur, bahan konstruksi bangunan dan ribuan aplikasi lainnya dimana logam yang mudah dibuat, kuat dan ringan diperlukan.[2]

Keausan terjadi apabila dua buah benda yang saling menekan dan saling bergesekan. Keausan yang lebih besar terjadi pada bahan yang lebih lunak. Faktor - faktor yang mempengaruhi keausan adalah kecepatan, tekanan, kekasaran permukaan dan kekerasan bahan. Semakin besar kecepatan relatif benda yang bergesekan, maka material semakin mudah aus. Demikian pula semakin besar tekanan pada permukaan benda yang berkontak, material akan cepat aus, begitu pula sebaliknya. Keausan yang mengakibatkan berkurangnya material - material pada benda akan menyebabkan kerusakan pada benda tersebut. Untuk mengatasi adanya keausan biasanya diberikan pelumas. [3] Tribologi adalah aspek yang berkenaan dengan gesekan, aus dan pelumasan. Secara prinsip, pelumasan berfungsi untuk mencegah keausan yang disebabkan oleh gesekan antar benda yang bergerak relatif. Disamping fungsi pelumas di atas, kegunaan yang lain adalah untuk mengurangi gesekan, sebagai seal kompresi, mengurangi noise, sebagai media pendingin komponen mesin, mengurangi karat, serta menjaga benda agar tetap bersih. Sebagai akibat dari hilangnya pelumas pada daerah boundary lubrication, maka keausan menjadi suatu hal yang tidak bias dihindari. Aus yang terjadi antara lain: adhesive wear, abrasive wear, surface fatigue wear dantribo chemical wear[4].

Penelitian lain Darmanto[5], Tahun 2014 dengan judul "Analisa Keausan Alumunium Menggunakan Tribotester Pin-On-Disk dengan Variasi Pelumas" Penelitian ini bertujuan untuk mengetahui pengaruh variasi kondisi pelumasan pada keausan material aluminium. Pin diuji dengan menggunakan pelumas SAE 40, SAE 140 dan tanpa pelumasan. Faktor keausan terbesar dalam penelitian yang telah dilakukan, terjadi pada pengujian dengan menggunakan pelumas SAE 40 sebesar 0,536.108m3/N.m diikuti pengujian dengan menggunakan pelumas SAE 140 sebesar 0,0507.10-8m3/N.m dan pengujian tanpa pelumas sebesar 10,477.10-8m3/N.m.

\section{METODOLOGI PENELITIAN}

Pasangan spesimen pada pengujian keausan ini menggunakan bahan aluminium 6020 alloy, komposisi kandungan unsur kimia pada material aluminium 6020 alloy pada tabel 1 berikut.

Tabel.1 Komposisi aluminium / aluminium 6020[6]

\begin{tabular}{l|llllllll}
\hline Element & $\boldsymbol{A l}$ & $\boldsymbol{S n}$ & $\boldsymbol{M g}$ & $\boldsymbol{S i}$ & $\boldsymbol{C u}$ & $\boldsymbol{F e}$ & $\boldsymbol{M n}$ & $\boldsymbol{Z n}$ \\
\hline Content & $93,9-$ & $0,90-1,5$ & $0,60-1,2$ & $0,40-$ & $0,30-$ & $\leq 0,50$ & $\leq 0,35$ & $\leq 0,20$ \\
$(\%)$ & 97,8 & & & 0,90 & 0,90 & & & \\
\hline
\end{tabular}

Pada nilai kekerasan aluminium 6020 alloy sebesar 63 HRB, dimana material ini banyak digunakan pada komponen otomotif diantaranya adalah piston rem, katup transmisi, piston kompresor AC dan lain sebagainya. Pada proses pengujian keausan dilakukan menggunakan alat uji two disk tribometer machine seperti pada Gambar 1. Alat uji ini dilengkapi dengan data acquisition untuk menampilkan laju rpm pada pengujian keausan yang terjadi gesekan pada dua spesimen. 


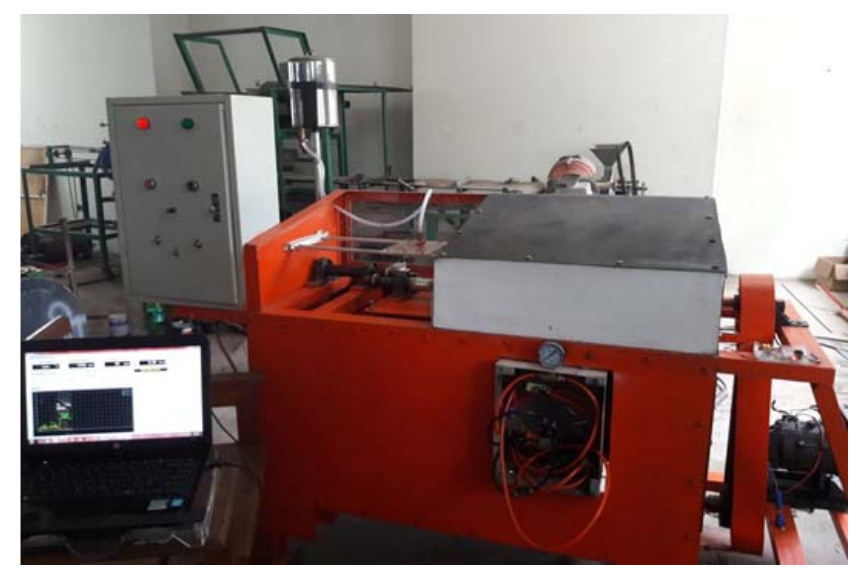

Gambar 1. Alat Uji Two Disk Tribometer berikut:

Prosedur pengujian keausan yang dilakukan dengan menggunakan alat uji two disk tribometer sebagai

a. Sebelum specimen diuji ditimbang terlebih dulu.

b. Pemasangan specimen pada alat uji two disc tribometer.

c. Mengatur pembebanan pada mesin.

d. Penyetelan putaran specimen dengan mengatur tombol pada pengatur Rpm 1 dan pengatur Rpm 2 .

e. Mulai proses pengujian keausan dengan melakukan pelumasan dan tanpa pelumasan selama 60 menit.

f. Setelah waktu pengujian selesai, timbang specimen.

Untuk menghitung besar volume aus material menggunakan persamaan berikut:

$\Delta \mathrm{V}=\frac{\hat{s} \mathrm{~m}}{\mathrm{p}}$

Keterangan :

$$
\begin{array}{ll}
\Delta \mathrm{V} & =\text { Perubahan volume } \operatorname{disk}\left(\mathrm{m}^{3}\right) \\
\Delta \mathrm{m} & =\text { Perubahanmassa } \operatorname{disk}(\mathrm{kg}) \\
\rho & =\text { Massa jenis disk }\left(\mathrm{kg} / \mathrm{m}^{3}\right) \\
\mathrm{t} & =\text { Waktu (menit) }
\end{array}
$$

Perubahan volume yang merupakan volume aus disk selanjutnya digunakan dalm menghitung besar laju keausan ( specific wear rate) dengan menggunakan persamaan Archad.

$\mathrm{K}=\frac{\Delta \mathrm{F}}{F \mathrm{~F}}$

Keterangan : $\quad \mathrm{K}=$ specific wear rate $\left(\mathrm{m}^{3} / \mathrm{N} . \mathrm{m}\right)$

$$
\begin{gathered}
\Delta F^{2}=\text { Perubahan Volume Disk }\left(\mathrm{m}^{3}\right) \\
\mathrm{F}=\text { Perubahanstatis }(\mathrm{N}) \\
\mathrm{L}=\text { Sliding distance }(\mathrm{m})
\end{gathered}
$$

Penyetelan kecepatan putar spesimen 1 dan spesimen 2 pada $1000 \mathrm{rpm}$. Waktu yang dipakai dalam proses pengujian keausan adalah selama 60 menit, setiap 10 menit dilakukan pengukuran kekasaran permukaan pada setiap spesimen seperti dalam Gambar 2, diameter spesimen masing - masing $50 \mathrm{~mm}$, tebal spesimen masing - masing $10 \mathrm{~mm}$, pada spesimen 1 dan spesimen 2 dibuat bidang kontaknya dengan radius $5 \mathrm{~mm}$. Pengujian keausan ini digunakan sistem pelumasan dengan minyak pelumas yang memiliki kekentalan SAE 10W-30 produksi Federal dan pengujian dengan tanpa pelumasan. Kegiatan pengujian keausan dilakukan di Laboratorium CNC Fakultas Teknik Program Studi Teknik Mesin Universitas Muria Kudus. 

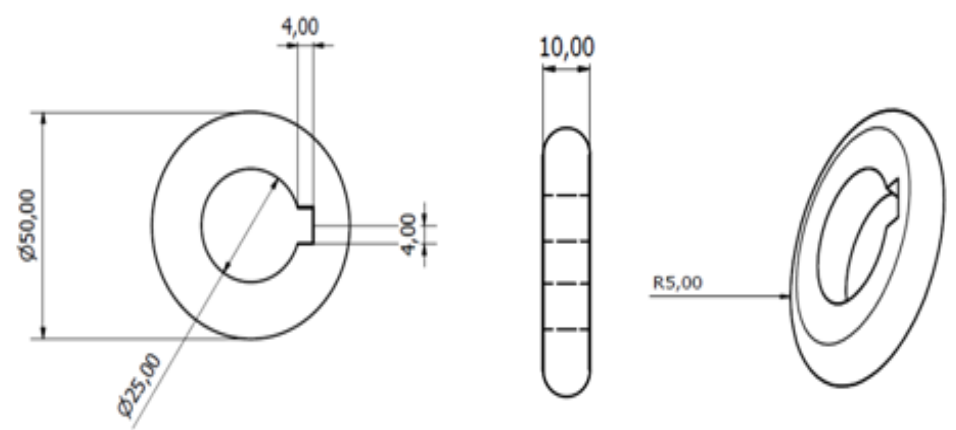

Gambar 2. Dimensi Spesimen Yang Dipakai Penelitian

Diagram alir pengujian keausan seperti terlihat pada gambar 3 dibawah ini diperlukan sebagai panduan agar semua kegiatan dapat berjalan dan mendapatkan hasil pengujian keausan yang baik dan benar.

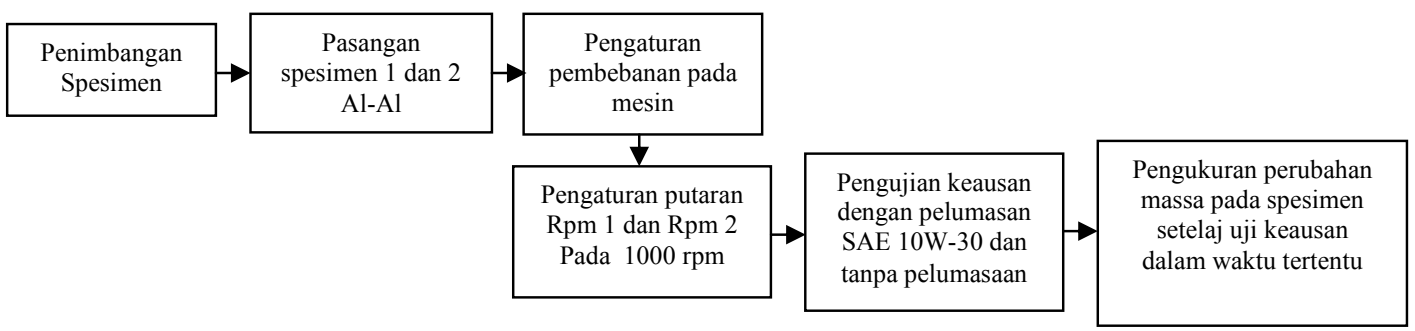

Gambar 3. Diagram Alir Pengujian Keausan

\section{HASIL DAN PEMBAHASAN}

\subsection{Pengujian Keausan dengan Pelumasan}

Pengujian keausan yang telah dilakukan dengan mesin two disk tribometerdengan pelumasan adalah perubahan nilai keausan pada kecepatan 1000 rpm berikut ini.

Tabel 1. Keausan specimen uji 1 aluminium dengan pelumasan 1000 rpm

\begin{tabular}{cccc}
\hline $\begin{array}{c}\text { Waktupengujian } \\
\text { (menit) }\end{array}$ & $\begin{array}{c}\text { Massaawal } \\
\text { (gram) }\end{array}$ & $\begin{array}{c}\text { Massaakhir } \\
\text { (gram) }\end{array}$ & $\begin{array}{c}\text { keausan } \\
\text { (gram) }\end{array}$ \\
\hline 10 & 35,76 & 35,564 & 0,196 \\
20 & 35,76 & 35,368 & 0,392 \\
30 & 35,76 & 35,172 & 0,588 \\
40 & 35,76 & 34,975 & 0,785 \\
50 & 35,76 & 34,778 & 0,982 \\
60 & 35,76 & 34,58 & 1,180 \\
\hline
\end{tabular}

Dari hasil pengujian keausan pada tabel 1 spesimen uji 1 aluminium dengan pelumasan pada 1000 rpm menujukkan penurunan berat spesimen uji yang sama setiap peningkatan waktu uji. Dan nilai keausan sebesar 0,0196 gram/menit dan nilai laju keausan selama 60 menit sebesar $0,000471 \mathrm{~mm}^{3} / \mathrm{N} . \mathrm{m}$

Perhitungan Laju Keausan

$$
\begin{aligned}
\text { Sv } & =\frac{\text { An }}{B} \\
& =\frac{\text { Adragram }}{\text { Gram } / \mathrm{cm}^{3}} \\
& =0,4354 \mathrm{~cm}^{3} \\
& =435,42 \mathrm{~mm}^{3} \\
\mathrm{~L} & =\text { kelilinglingkaran } \\
\mathrm{L} & =2 \cdot \pi \cdot \mathrm{r}
\end{aligned}
$$




$$
\begin{aligned}
& =2 \cdot 3,14.0,025 \\
& =0,157 \mathrm{~m}
\end{aligned}
$$

Jaraktempuhuntukkecepatan 1000 rpm selama 60 menit :

$\mathrm{L} \quad=0,157.1000 .60$

$=9420 \mathrm{~m}$.

Perubahan volume yang merupakan volume aus disk selanjutnya digunakan dalm menghitung besar laju keausan ( specific wear rate) dengan menggunakan persamaan Archad.

$$
\begin{aligned}
& \mathrm{K}=\frac{\Delta \mathrm{v}}{E \boldsymbol{E}} \\
& =482-42 \mathrm{~mm}^{\mathrm{2}} \\
& \text { F81 } \\
& =\frac{21.6 \mathrm{~mm}}{824102 \mathrm{Nm}} \\
& =0,000471 \mathrm{~mm}^{3} / \mathrm{N} \cdot \mathrm{m}
\end{aligned}
$$

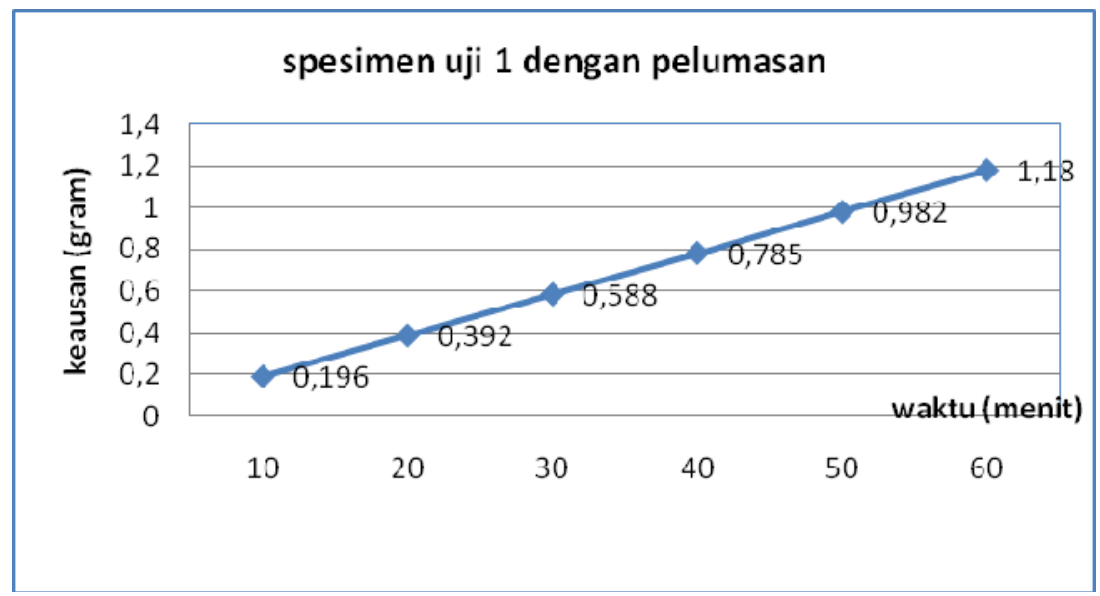

Gambar 4. Grafik keausan spesimen uji 1 dengan pelumasan

Pada gambar 3 menunjukkan trend keausan pada spesimen uji 1 meningkat setiap pada 10 menit keausan sebesar 0,196 gram/menit keausan paling besar pada menit ke 60 sebesar 1,18 gram.

Tabel 2. Keausan specimen uji 2 aluminium dengan pelumasan 1000 rpm

\begin{tabular}{cccc}
\hline $\begin{array}{c}\text { Waktupengujian } \\
\text { (menit) }\end{array}$ & $\begin{array}{c}\text { Massaawal } \\
\text { (gram) }\end{array}$ & $\begin{array}{c}\text { Massaakhir } \\
\text { (gram) }\end{array}$ & $\begin{array}{c}\text { keausan } \\
\text { (gram) }\end{array}$ \\
\hline 10 & 34,76 & 34,564 & 0,193 \\
20 & 34,76 & 34,368 & 0,386 \\
30 & 34,76 & 34,172 & 0,579 \\
40 & 34,76 & 33,975 & 0,772 \\
50 & 34,76 & 33,778 & 0,966 \\
60 & 34,76 & 33,58 & 1,160 \\
\hline
\end{tabular}

Dari hasil pengujian keausan pada tabel 2 spesimen uji 2 aluminium dengan pelumasan pada 1000 rpm juga menujukkan penurunan berat spesimen uji yang sama setiap peningkatan waktu uji. Dan nilai keausan sebesar 0,0193 gram/menit dan nilai laju keausannya selama 60 menit sebesar $0,000462 \mathrm{~mm}^{3} / \mathrm{N} . \mathrm{m}$ 


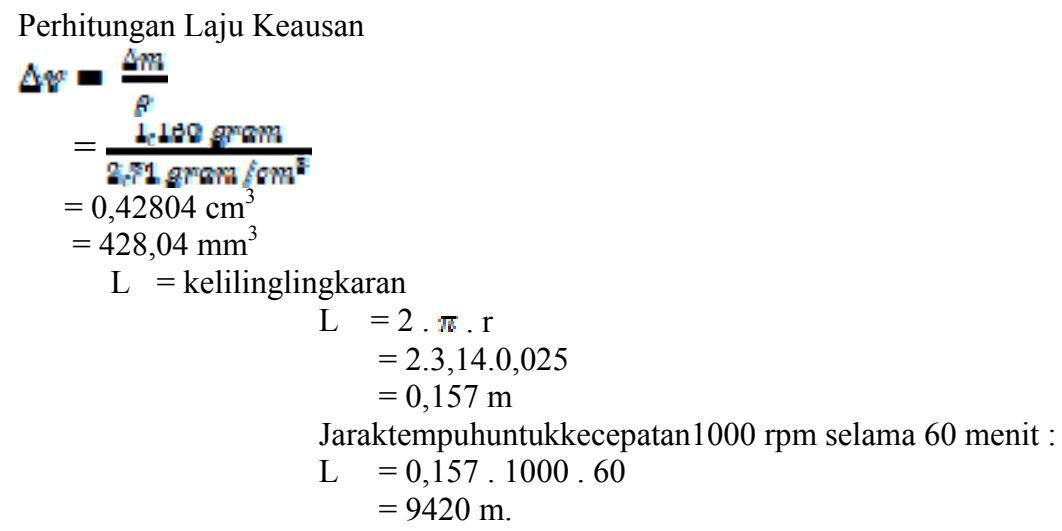

Perubahan volume yang merupakan volume aus disk selanjutnya digunakan dalm menghitung besar laju keausan ( specific wear rate) dengan menggunakan persamaan Archad
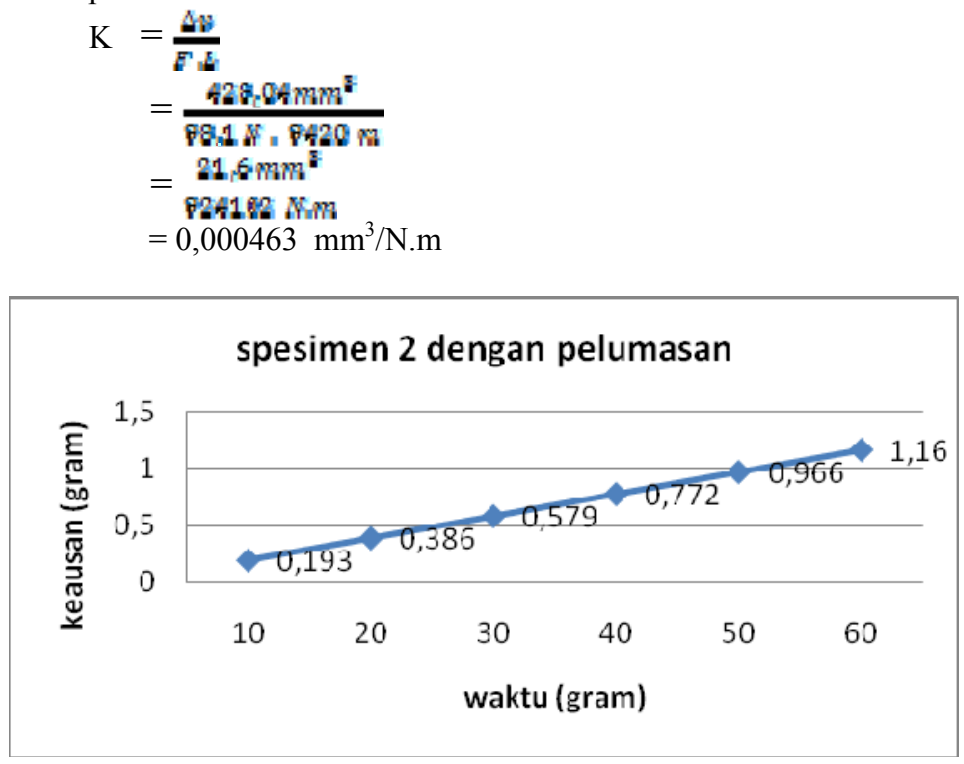

Gambar 5. Grafik keausan spesimen uji 2 dengan pelumasan

Pada gambar 4 menjukan penurunan pada spesimen 2 dibandingkan dengan spesimen 1 itu terjadi tidak stabilnya putaran sedangkan spesimen 1 menunjukan tetap naik keausannya sebesar 0,196 gram/menit

\subsection{Pengujian Keausan Tanpa Pelumasan}

Pengujian keausan yang telah dilakukan dengan mesin two disk tribometertanpa pelumasan adalah perubahan nilai keausan pada kecepatan 1000 rpm berikut ini.

Tabel 3. Keausan specimen uji 1 aluminium tanpa pelumasan 1000 rpm

\begin{tabular}{cccc}
\hline $\begin{array}{c}\text { Waktupengujian } \\
\text { (menit) }\end{array}$ & $\begin{array}{c}\text { Beratawal } \\
\text { (gram) }\end{array}$ & $\begin{array}{c}\text { Beratakhir } \\
\text { (gram) }\end{array}$ & $\begin{array}{c}\text { Beratkeausan } \\
\text { (gram) }\end{array}$ \\
\hline 10 & 34,87 & 34,544 & 0,326 \\
20 & 34,87 & 34,218 & 0,652 \\
30 & 34,87 & 33,892 & 0,978 \\
40 & 34,87 & 33,565 & 1,305 \\
50 & 34,87 & 33,238 & 1,632 \\
60 & 34,87 & 32,91 & 1,96 \\
\hline
\end{tabular}


Dari hasil pengujian keausan pada tabel 3 spesimen uji 1 aluminium tanpa pelumasan pada 1000 rpm menujukkan penurunan berat spesimen uji yang sama setiap peningkatan waktu uji. Dan nilai keausan sebesar 0,0326 gram/menit dan nilai laju keausannya selama 60 menit sebesar 0,000782 $\mathrm{mm}^{3} / \mathrm{N}$.m.

$$
\begin{aligned}
& \text { Perhitungan Laju Keausan } \\
& \Delta v=\frac{\Delta m}{f} \\
& =1 . \nabla C Q \text { aram } \\
& \text { 2.71 a ram } / \mathrm{gm}^{2} \\
& =0,72324 \mathrm{~cm}^{3} \\
& =723,24 \mathrm{~mm}^{3} \\
& \mathrm{~L}=\text { kelilinglingkaran } \\
& \mathrm{L}=2 . \pi . \mathrm{r} \\
& =2.3,14.0,025 \\
& =0,157 \mathrm{~m}
\end{aligned}
$$

Jaraktempuhuntukkecepatan1000 rpm selama 60 menit :

$$
\begin{aligned}
\mathrm{L} & =0,157.1000 .60 \\
& =9420 \mathrm{~m} .
\end{aligned}
$$

Perubahan volume yang merupakan volume aus disk selanjutnya digunakan dalm menghitung besar laju keausan (specific wear rate) dengan menggunakan persamaan Archad

$$
\begin{aligned}
& \mathrm{K}=\frac{\Delta v}{E \cdot \underline{v}} \\
& =725.24 \mathrm{~mm}^{2} \\
& \text { PQ1 A P P2O m } \\
& =728.94 \mathrm{~mm}^{\mathrm{F}} \\
& \text { F2A1" kfm } \\
& =0,000782 \mathrm{~mm}^{3} / \mathrm{N} . \mathrm{m}
\end{aligned}
$$

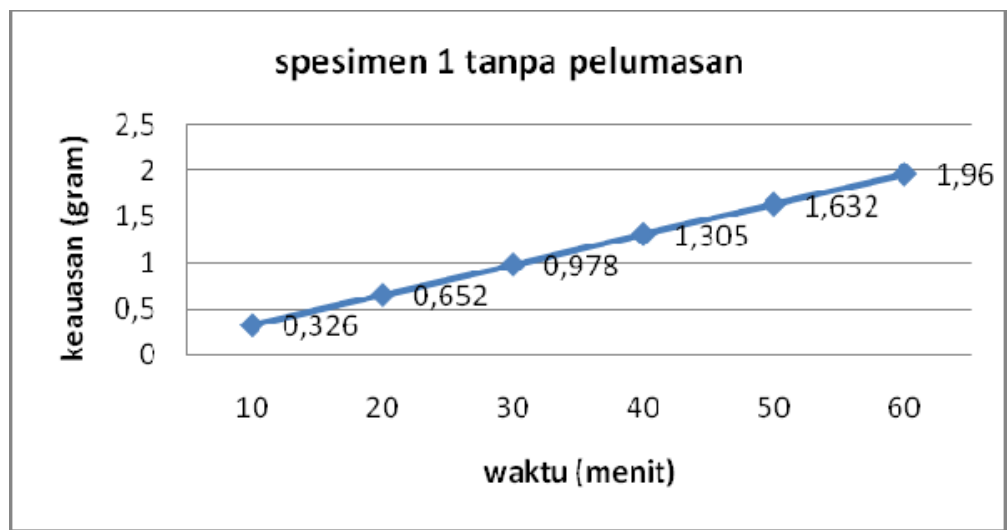

Gambar 6. Grafik Keausan Spesimen Uji 1 Tanpa Pelumasan

Pada gambar 5 menunjukkan trend keausan pada spesimen uji 1 tanpa pelumasan meningkat setiap pada 10 menit keausan sebesar 0,326 gram/menit keausan paling besar pada menit ke 60 sebesar 1,632 gram

Tabel 4. Keausan spesimen uji 2 aluminium tanpa pelumasan 1000 rpm

\begin{tabular}{cccc}
\hline $\begin{array}{c}\text { Waktu pengujian } \\
\text { (menit) }\end{array}$ & $\begin{array}{c}\text { Berat awal } \\
\text { (gram) }\end{array}$ & $\begin{array}{c}\text { Berat akhir } \\
\text { (gram) }\end{array}$ & $\begin{array}{c}\text { Berat keausan } \\
\text { (gram) }\end{array}$ \\
\hline 10 & 34,86 & 34,532 & 0,328 \\
20 & 34,86 & 34,204 & 0,656 \\
30 & 34,86 & 33,876 & 0,984 \\
40 & 34,86 & 33,548 & 1,312 \\
50 & 34,86 & 33,219 & 1,641 \\
60 & 34,86 & 32,89 & 1,970 \\
\hline
\end{tabular}


Dari hasil pengujian keausan pada tabel 4 spesimen uji 2 aluminium tanpa pelumasan pada 1000 rpm menujukkan penurunan berat spesimen uji yang sama setiap peningkatan waktu uji. Dan nilai keausan sebesar 0,0328 gram/menit Dan nilai keausan sebesar 0,0326 gram/menit dan nilai rata-rata laju keausannya sebesar $0,000786 \mathrm{~mm}^{3} / \mathrm{N} . \mathrm{m}$

$$
\begin{aligned}
& \text { Perhitungan Laju Keausan } \\
& \Delta N=\frac{\Delta m}{f} \\
& =\frac{1.879 \text { qmam }}{2.71 \text { gram } / \mathrm{gm}^{2}} \\
& =0,72693 \mathrm{~cm}^{3} \\
& =726,93 \mathrm{~mm}^{3} \\
& \mathrm{~L}=\text { kelilinglingkaran } \\
& \mathrm{L}=2 . \pi \cdot \mathrm{r} \\
& =2.3,14.0,025 \\
& =0,157 \mathrm{~m}
\end{aligned}
$$

Jaraktempuhuntukkecepatan1000 rpm selama 60 menit :

$$
\begin{aligned}
\mathrm{L} & =0,157.1000 .60 \\
& =9420 \mathrm{~m} .
\end{aligned}
$$

Perubahan volume yang merupakan volume aus disk selanjutnya digunakan dalm menghitung besar laju keausan (specific wear rate) dengan menggunakan persamaan Archad.

$$
\begin{aligned}
& \mathrm{K}=\frac{\Delta w}{E \underline{E}} \\
& =\frac{726.80 \mathrm{~mm}}{881.48,8420 \mathrm{~m}} \\
& =\frac{726 . \mathrm{Famm}}{} \\
& \text { P2A1/2 Km } \\
& =0,000786 \mathrm{~mm}^{3} / \mathrm{N} . \mathrm{m}
\end{aligned}
$$

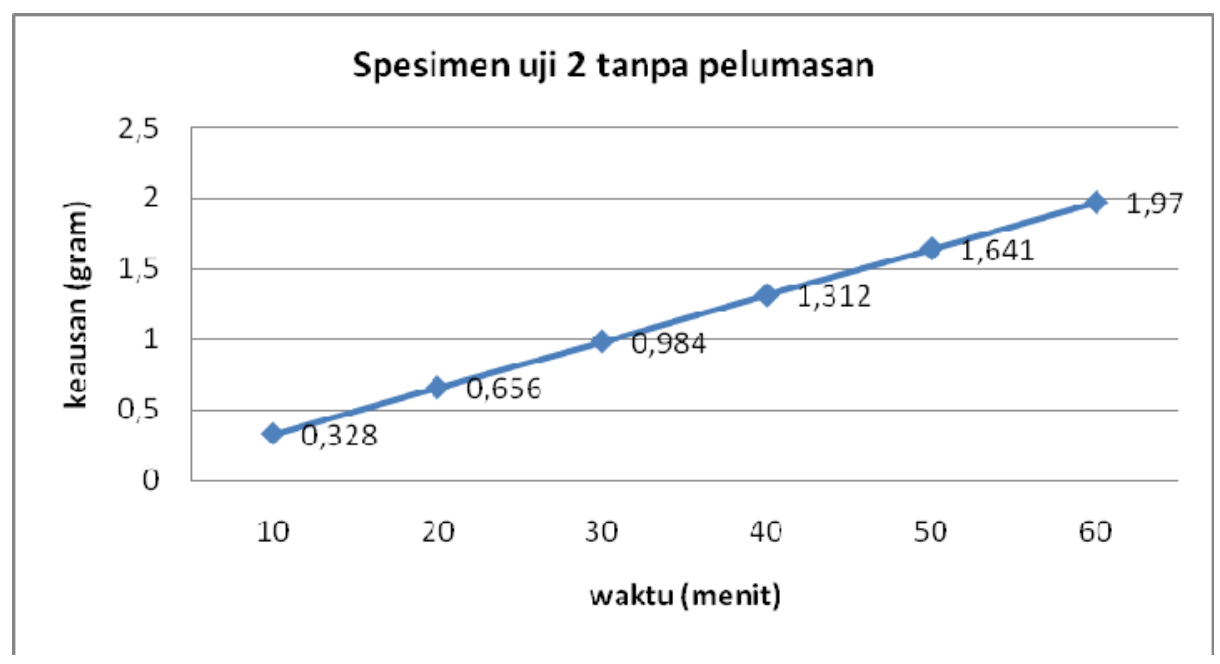

Gambar 7. Grafik Keausan Spesimen Uji 2 Tanpa Pelumasan

Pada gambar 6 menunjukkan trend keausan pada spesimen uji 2 tanpa pelumasan meningkat setiap pada 10 menit keausan sebesar 0,328 gram/menit keausan paling besar pada menit ke 60 sebesar 1,970 gram. 


\subsection{Perbandingan Uji Keausan Dengan Pelumasan Dan Tanpa Pelumasan}

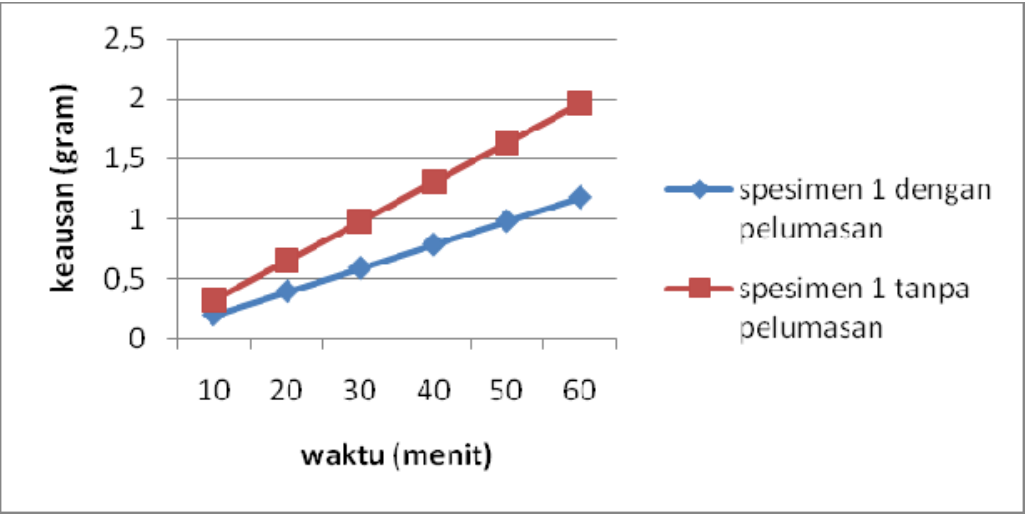

\section{Gambar 8. Grafik Perbandingan Spesimen 1 Dengan Pelumasan dan Tanpa Pelumasan}

Pada gambar 7 grafik diatas pada spesimen 1 keausan terendah adalah keausan pada menit 60 dengan pelumasan dengan berat keausan 1,180 gram dan nilai laju keausan sebesar $0,000471 \mathrm{~mm}^{3} / \mathrm{N} . \mathrm{m}$ sedangkan keausan terbesar pada grafik menunjukan keausan tanpa menggunakan pelumasan dengan nilai 1,960 gram dan nilai laju keausan sebesar $0,000786 \mathrm{~mm}^{3} / \mathrm{N} . \mathrm{m}$.

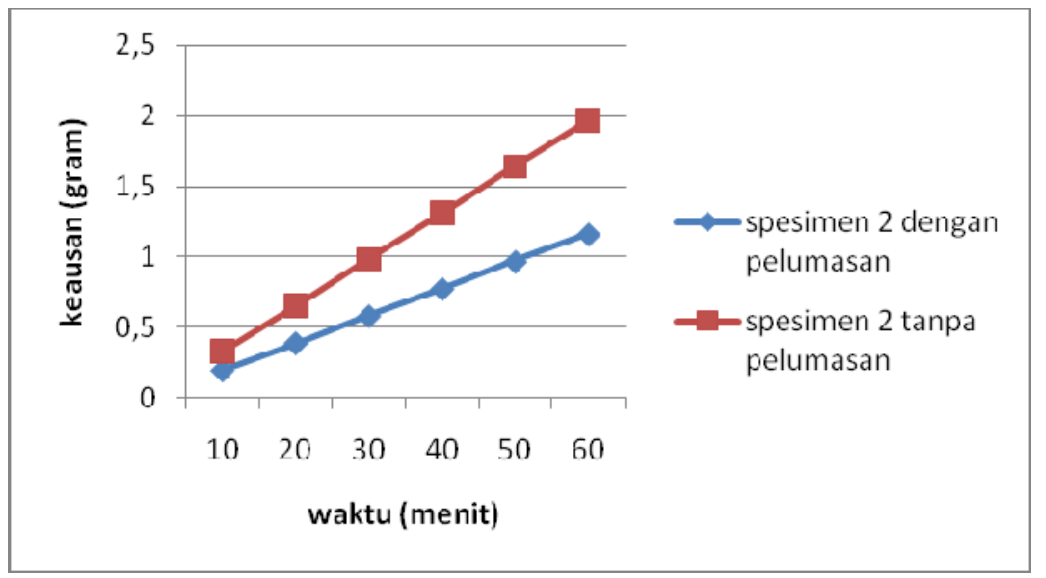

\section{Gambar 9. Grafik Perbandingan Spesimen 2 Dengan Pelumasan dan Tanpa Pelumasan}

Pada gambar 8 grafik diatas pada spesimen 2 keausan terendah adalah keausan pada menit 60 dengan pelumasan dengan berat keausan 1,160 gram dan nilai laju keausan sebesar $0,000463 \mathrm{~mm}^{3} / \mathrm{N} . \mathrm{m}$ sedangkan keausan terbesar pada grafik menunjukan keausan tanpa menggunakan pelumasan dengan nilai 1,970 gram dan nilai laju keausan sebesar $0,000782 \mathrm{~mm}^{3} / \mathrm{N} . \mathrm{m}$.

\section{KESIMPULAN}

Hasil pengujian keausan pada spesimen yang terbuat dari material aluminium 6020 alloy dengan menggunakan pelumasan SAE 10W-30 dan tanpa pelumasan memperoleh kesimpulan bahwa setiap menit keausan pada disk meningkat, keausan dengan pelumasan mempengaruhi laju keausan pada spesimen uji dengan nilai rata-rata laju keausannya sebesar $0,000466 \mathrm{~mm}^{3} / \mathrm{N} . \mathrm{m}$, sedangkan rata-ratalaju keausan pada tanpa pelumasan sebesar $0,000784 \mathrm{~mm}^{3} / \mathrm{N}$.m. Laju keausan tanpa pelumasan lebih besar dari laju keausan dengan menggunakan pelumasan. 


\section{DAFTAR PUSTAKA}

[1] Surdia T., dan Saito S. (1999). Pengetahuan Bahan Teknik, Cet, 4 PT. Pradnya Paramita. Jakarta.

[2] Ikhwansyah Isranuri, Suprianto, Wendy Aditya, 2012. Analisa Pengaruh Beban Terhadap Laju Keausan Al-Si Alloy Dengan Metode Pin On Disk Test. Departemen Teknik Mesin Fakultas Teknik Universitas Sumatera Utara.

[3] Tarina W., 2012. Studi Eksperimental Laju Keausan (Specific Wear Rate) Resin Akrilik dengan Penambahan Serat Penguat pada Dental Prosthesis. Jurusan Teknik Mesin, Fakultas Teknologi Industri, Institut Teknologi Sepuluh Nopember (ITS). Surabaya.

[4] Syafa'at., 2008. Tribologi, Daerah Pelumasan Dan Keausan. Jurusan Teknik Mesin, Fakultas Teknik Universitas Wahid Hasyim Semarang.

[5] Darmanto, Muhamad Thufik Ridwan, Imam Syafa'at, 2014. Analisis Keausan Alumunium Menggunakan Tribotester Pin-On-Disc Dengan Variasi Kondisi Pelumas. Jurusan Teknik Mesin, Fakultas Teknik, Universitas Wahid Hasyim. Semarang.

[6] ZoM, 2013, Aluminium / Aluminum 6020 Alloy (UNS A96020). 